$\begin{gathered}\text { EPiC Series in Education Science } \\ \text { Volume 1, 2017, Pages 165-178 }\end{gathered}$
$\begin{gathered}\text { AUBEA 2017: Australasian Universities Build- } \\ \text { ing Education Association Conference 2017 }\end{gathered}$

\title{
The Australian Residential Property Market: A Study on Foreign Real Estate Investment
}

\author{
P. Wong ${ }^{1}$ and R. Wakefield ${ }^{1}$ \\ ${ }^{1}$ RMIT University, Melbourne, Australia. \\ peng.wong@rmit.edu.au, ron.wakefieldermit.edu.au
}

\begin{abstract}
This research focuses on determining the significance of foreign investment in the Australian residential property market subsequent to the Global Financial Crisis 2008. Quantitative models built on secondary data were tested on two residential property markets comprising Metropolitan Melbourne and a key suburb in the Victoria State, Australia. The relationship between the house price performances and various leading offshore and local Australian economic indicators were assessed. As a result of the increasing relevance of globalisation and Asia Pacific private wealth in the Australia, foreign real estate investment has impacted significantly the Melbourne residential property market performance. The result of this study provides a better understanding on the relationship between the Australian residential property market performance and the emerging significance of the foreign investment drivers. A better understanding of these foreign investment determinants will assist policy makers to effectively manage the Australian residential property market without compromising the steady flow of foreign real estate investment. The result of this study is believed to yield findings that can assist the researcher, property market operators and investors in the evaluation of foreign investments in the Australia residential housing market.
\end{abstract}

Keywords: Australia, Residential Property, Housing Markets, Foreign Real Estate Investment (FREI), Asia Pacific Private Wealth. 


\section{INTRODUCTION}

\subsection{The Australian Residential Property Market}

Australian capital city house prices grew 1.4 per cent in December from November in 2016 with an annual growth of 10.9 per cent since 2015, representing the fastest pace since Global Financial Crisis (GFC) 2008 (Glynn, 2017). House prices in both Sydney and Melbourne were at record levels and the media alleged that house prices in Australia went beyond the reach of the majority local buyers especially in desirable locations since 2014 (AFP, 2014, Birrell, 2013, Economics, 2014). Subsequent to the GFC 2008 the national dwelling prices rose by $19 \%$ whilst the household incomes rose by a mere $9.2 \%$ as per estimates from the ANU Centre for Social Research and Methods. In September 2016, the national house price to income ratio was 6.9 times $(7.2$ times for houses and 6.4 times for units) compares to 4.3 times (4.2 times for houses and 4.8 times for units) 15 years ago. $36.8 \%$ of a household's income was required to service an $80 \%$ Loan Value Ratio (LVR) mortgage in September 2016 compares to $26.8 \%$ of household income in September 2001 (CoreLogic, 2016).

The National Australian Bank highlighted that the Foreign Real Estate Investment (FREI) could have been the cause for the Australian capital cities house prices to rise by $6.0 \%$ in 2014 and $5.0 \%$ in 2015 in the. Approximately $16 \%$ of the total sales in Australian new housing markets were transacted into the hands of foreign buyers in 2015, where foreign buyers' involvement reached $21 \%$ in NSW and Victoria (NAB, 2015). AFP (2014) estimated that $18 \%$ of new dwellings in Sydney and $14 \%$ in Melbourne were purchased by foreigners in 2014. Chinese investors and newly arrived migrants were singled out as the major FREI buyers in Australia and they are expected to invest approximately AUD44 billion into Australia residential real estate market by 2021 (Janda, 2014). Figure 1 shows the trend of number of residential real estate approvals for foreign investors in Australia from 2006 to 2012.

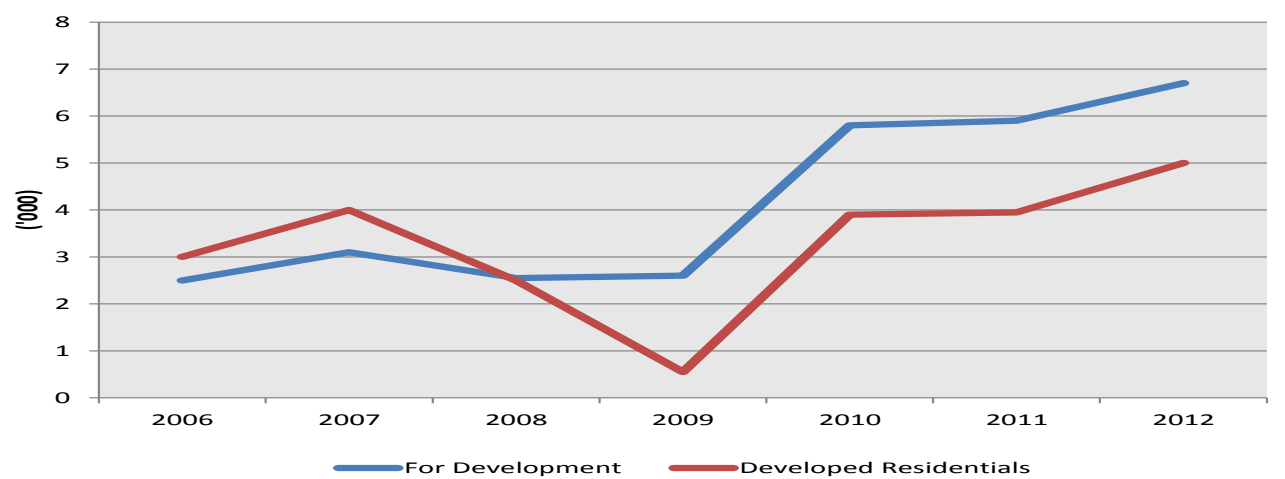

Figure 1: Residential Real Estate Approvals for Foreign Investors (Source: FIRB 2014)

Figure 1 shows the significant lift in both the Australian house prices and the foreign interest in the Australian residential property market. In 2014 the Australian treasurer initiated a formal inquest to the Australian Foreign Investment Review Board (FIRB) to investigate into the Australia's foreign investment policy related to Australian residential real estate. In his reply to the inquest, FIRB chairman Brian Wilson explained that although it was 
the government's intention to control illegal buying of Australian residential properties, the ability to uncover and prosecute illegal buying by foreigners was limited (Rose, 2015). In the midst of media highlights on the foreign buying being the main reason for the rising house prices, equally noteworthy reports emerged suggesting that FREI may have played relatively minor role in the Australian house price growth (Guest and Rohde, 2015, Soos, 2012). Commonwealth Bank (2014) explained that foreign investors' demand was only a marginal contributing factor to the hike in Sydney and Melbourne house prices.

There are clear indications for a need to research on the FREI activities in the Australian residential property market. The focus of this study is to determine whether there are historical evidences of a relationship between overseas investments and the residential housing markets performance in Melbourne. This study is expected to yield empirical evidence that will assist the Australian policies makers in harmonising the much needed foreign investments yet maintaining the affordability of housing market in Australia. The findings of this study can assist the researcher, property market operators and investors conducting evaluation on the Australia residential housing market.

\section{LITERATURE REVIEW}

\subsection{FREI and the Traditional Determinants}

In this global liberalisation era, the potential benefits derived from the international real estate investment strategies resulted in the inclusion of real estate as a common asset class in any international investment portfolio analysis (Sirmans and Worzala, 2003). The real estate sector had successfully attracted significant interest from international investors, due to its increasing level of liquidity, superior returns and improved opportunities for diversification (D'Arcy, 2009, Topintzi et al., 2008). Other empirical studies seem to suggest that international real estate investment could be regarded as a hedge against excessive risks associated with equity investments (Fereidouni and Tajul Ariffin, 2013, Hoesli, 2004, Moshirian, 1999, Sirmans, 2003, Wilson, 2003). Evidently, cross border foreign real estate investments is on the rise in this global liberalization era (D'Arcy, 2009, Topintzi et al., 2008, UNCTAD, 2009, UNCTAD, 2013).

Foreign Direct Investment (FDI) in real estate markets had experienced significant growth in many countries (UNCTAD, 2011). The increasing cross border activities in real estate market was particularly noticeable in China which observed FDI in real estate market went up to almost $50 \%$ of the total China's FDI in 2012. In India, real estate ranked second only to India's computer software industry in 2007 FDI (Economist, 2008). Evidently, cross border foreign real estate investments is on a rise in this global liberalization era (D'Arcy, 2009, Topintzi et al., 2008, UNCTAD, 2009, UNCTAD, 2013).

The main attractions cited for the top foreign investment destinations include stable political and social environments, sound legal and regulatory systems, successful market system, and leading competence in science and technology and education. The drivers cited by Schiesinger (2015) on FREI buying into Australian residential property market were better investment fundamentals, the opportunity to acquire freehold property, higher yields, more stable economic environment and the ability to borrow up to $80 \%$ in Australia. The other two main reasons were availability of education for children to study in Australia and this in turn 
forms part of a future plan to migrate to Australia due to better living conditions (KPMG, 2014). Other major factors that drove the housing market demand in Australia include:

i. The population growth attributable by an increased level of skilled migrant intake. The recent migrants were equity strong and they purchased residential properties sooner than many unskilled migrants.

ii. Competition with mining and infrastructure for skilled labour and materials had limited the supply of residential properties.

iii. Higher number of granted education visas.

iv. Real estate has a proven track record for self-managed super funds.

Source: CommonwealthBank 2014

In the midst of FREI activities in the Australian residential property market, Commonwealth Bank (2014) highlighted that the normal investment theory and law of demand and supply was perceived inadequate to explain the reasons of offshore investors' preference in Australia residential properties over other parts of the world. There is an apparent lacking of studies assessing the recent real estate investment decision models from a different perspective based on the emergence of new economic fundamentals subsequent to GFC 2008. A more extensive research into factors causing the surge of housing demand in Australia cities has become desirable.

\subsection{FREI subsequent to GFC 2008}

Capgemini (2015) and Savills (2014) identified two emerging trends in FREI that will have a significant impact on the world real estate market. The Asia Pacific private wealth and High Net Worth Individuals (HNWIs) are set to overtake western countries' HNWIs as the biggest investor in global property market investments. A new trend has emerged after the GFC 2008 as the sovereign wealth funds, wealth management companies, private bankers and wealthy families have stepped into the property market arena that corporate bankers have deserted and many of them purchased residential properties. Figure 2 demonstrates the trends and compositions of private investment in global real estate for the period of 2007 to 2012.

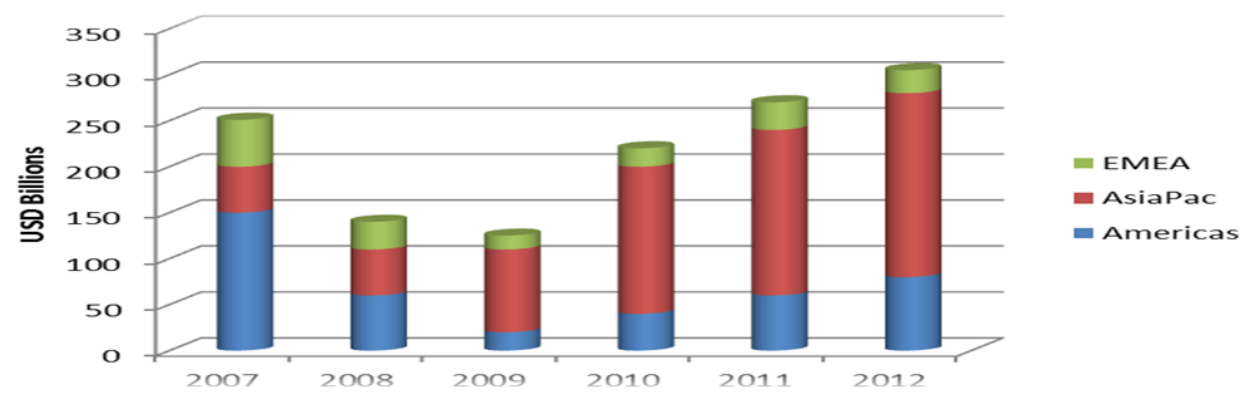

Figure 2: Private Wealth Investment in Global Real Estate (Source: Savills 2014)

Figure 2 reveals that the private wealth investment in global real estate had recovered from the low levels of 2009. Private wealth investment in global real estate had surpassed the highest level in 2007 and attained USD300 billion in 2012. The increasing Asia Pacific private wealth was the key driver that to the cross border investment activities seeking higher return and diversification (KPMG, 2014, Savills, 2014). The growth of High Net Worth 
Individuals (HNWI) in Asia and their investments in cross-border real estate transactions had impacted the world real estate investment landscape (KPMG, 2014). The rising private wealth in Asia Pacific was believed to be the driver that increased the cross border investment activities seeking higher return and diversification and many of them purchases overseas residential properties (KPMG, 2014, Savills, 2014).

\section{THE MODEL}

This research intends to rely extensively on a research model providing the much needed systematic platform for both local and FREI determinants investigation. Offshore elements and influences will be systematically built into the research modelling to facilitate organised analysis on various capitalist factors. Following the review of various studies conducted specifically on FDI investments abroad, it is conclusive that of equal importance, if not more, should be placed on the investigation on the source of FDI in determining the factors affecting FDI in the host country. Exchange rates, size of the share market, balance of payments, trade flows, cost of capital, economic growth were identified as major "push factors" for investment in real estate abroad (Culem, 1988, Cushman ,1987, Frey et al., 1985, Froot et al., 1991, Goldberg and Johnson, 1990, Moshirian and Pham, 2000, Nigh, 1986). Instead of merely conducing studies relying on local factors, Figure 3 illustrates the proposed "Higgins \& Peng" model providng an additional assessment platform accomodating the impactful influnces exerted from the overseas on the local market (Wong, 2017):

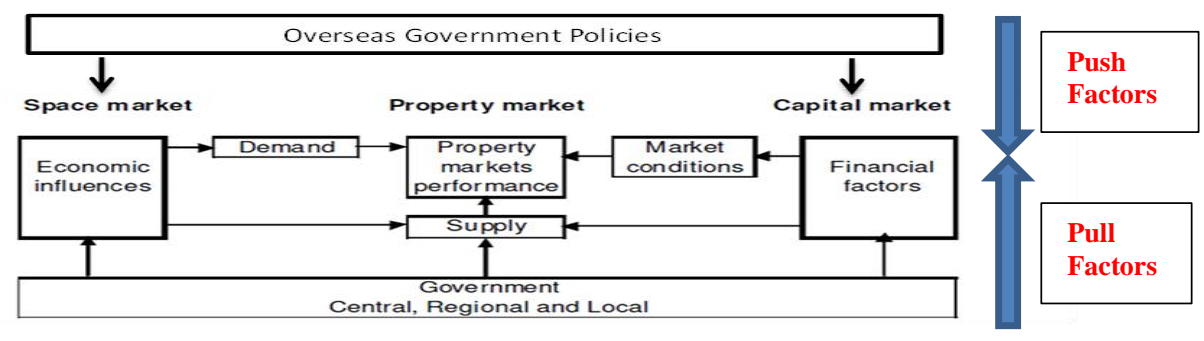

Figure 3: The "Higgins \& Peng" Model

Figure 3 illustrates an added component of 'Overseas Government Policies' (from which the offshore investors originated) that impacts and influences the space and capital markets of the host country were duly incorporated in the "Higgins \& Peng" model. It is believed that the resultant economy conditions of the offshore government policies have meaningful influences over the foreign investment outflow from the source country and emerges as impactful effects over the Space and Capital market in the host country. Importantly property market supply conditions are very much associated with the policy implementation of local government agencies or in other words, not related to offshore government policies. The "Higgins \& Peng" model provides the fundamental platform of assessment for various determinants of foreign investments into the Melbourne residential property market for this study. 


\section{QUANTITATIVE FORECASTING MODEL}

A predictive quantitative design involves correlational research and uses statistical analysis on the relationship between two or multiple variables to forecast the future (Tashakkori, 2010). This research falls into this classification of "predictive" design method, whereby house price performance in the selected suburbs will be forecasted to predict the future trend and to validate the model. Quarterly median house prices starting from the year 2003 to 2013 are collected for Australia, Melbourne Metropolitan and the one representative suburbs from the ABS and the Real Estate Institute of Victoria (REIV) database. Factors associated with the foreign investment were analysed alongside with the traditional leading economic indicators in both correlations and regression analysis to explore the interrelationship of the house prices and the leading economic indicators. Three statistical analysis methods were applied to analyse the strength of the relationships between the Dependant Variables (DV), ie. Quarterly Median House Price Movements and the Quarterly Independent Variable Movements (IV) from 2003 to 2013, ie. the Australian Leading Economic Indicators to confirm the validity of the model, namely:

i. Lagged Economic Indicators - the IVs will be lagged for eight quarters or a two-year lag to provide sufficient time for the macroeconomic activities to flow on to the residential property performance.

ii. Correlation Matrix Pearson Correlation Coefficient $\left(R^{2}\right)$ - to analyse the nature and relationship between the key economic factors of Australia against the house prices of the selected area of interest. ' $\mathrm{t}$ ' tests at the 95\% and 99\% confidence levels are applied.

iii. Multiple Linear Stepwise Regression - using the ordinary least squares method, forecasting models are built to predict that the relationship between the predictor (IV) and DV. The single regression equation to assess the correlations between the house prices and various independent variables can be expressed as:

\begin{tabular}{ll} 
Regression Model & Equations \\
\hline $\begin{array}{l}\text { (HOUSE PRICE MOVEMENT)+ } \\
f\left(\text { Space datasets }+\ldots+-_{2}, \ldots\right)+\left(\text { Capital datasets }+\ldots+-_{2}, \ldots\right) \\
+\left(\text { Property datasets }+\ldots+-_{2}, \ldots\right)\end{array}$ \\
\hline
\end{tabular}

Three key statistical tests are used to confirm the validity of the residential property forecast model:

i. Coefficient of determinant $\left(R^{2}\right)-R^{2}$ reflects the proportion of variability in the DV that can be explained by a linear relationship with the predictor variables.

ii. Sig-value or $p$-value - If the Sig-value or p-value is less than 0.05 significant levels, we reject $\mathrm{H}_{0}$. There is statistically significant evidence that the data fits a linear regression model

iii. Statistical test for bias (t-test) - to determine if there is bias and the errors are normally, or nearly normally, distributed.

iv. Durbin Watson Statistics (DW) - this is a test to detect patterns in a series of errors.

The main statistical software for this analysis was SPSS. The subprogram 'Multiple regressions: enter, stepwise and forward models were used to provide an acceptable regression equation to assess the correlations and predict future residential property 
performance. A significance level of 0.05 with a non-zero intercept was chosen as the model parameter.

\section{OUTCOME}

Part one of the quantitative research involves descriptive analysis on a decade of ABS census data and the market updates in search of a suburb in the Australian State of Victoria that attracted the most overseas settlers between 2003 and 2013. Clayton's house prices increased the most during the assessment period. House prices in Clayton increased by $120 \%$ comparing 2002 and 2013. Melbourne Metropolitan and Australian house prices had increased $60 \%$ and $40 \%$ respectively.

In part two of this research, statistical testing techniques including Pearson Correlation Coefficient and Stepwise Time Series Regression were employed to provide two forecasting models to confirm the validity of determinants. The market capitalist factors were evaluated both in terms of correlation and significance in relation to the individual market residential property market performance. The result of the stepwise multiple regression analysis is presented in Table 1:

\begin{tabular}{|c|c|c|c|c|c|c|c|}
\hline Melbourne Metropolitan & & $R^{2}=97.2 \%$ & & & & & \\
\hline Variables & Description & Lagged & B-value & Coefficient & T-test & Sig. & DW test \\
\hline 1 10BondCurr & 10-year Government Bond Yield & Current & 0.311 & 0.614 & 13.566 & 0 & \\
\hline 2 BuiltCurr & Building Plannings Approval & Current & 0.203 & 0.391 & 8.279 & 0 & \\
\hline 3 Forex5 & Foreign Currency Exchange & 15 months & -0.18 & -0.249 & -5.23 & 0 & \\
\hline 4 GDP6 & GDP Growth & 18 months & -1.404 & -0.167 & -3.552 & 0.002 & \\
\hline 5 ASXCurr & ASX 200 Index & Current & -0.05 & -0.171 & -4.446 & 0 & \\
\hline 6 NewHse5 & New Housing Supply & 15 months & -0.085 & -0.141 & -3.486 & 0.002 & \\
\hline 7 NOM5 & Net Overseas Migration & 15 months & 0.074 & 0.231 & 3.376 & 0.002 & 2.595 \\
\hline
\end{tabular}

Multiple Linear Regression Equation =

2.38+0.311(10BondCurrent)+0.203(BuiltCurr)-0.18(Forex5)-1.404(GDP6)-0.05(ASXCurr)-0.085(NewHse5)+0.074(NOM5)

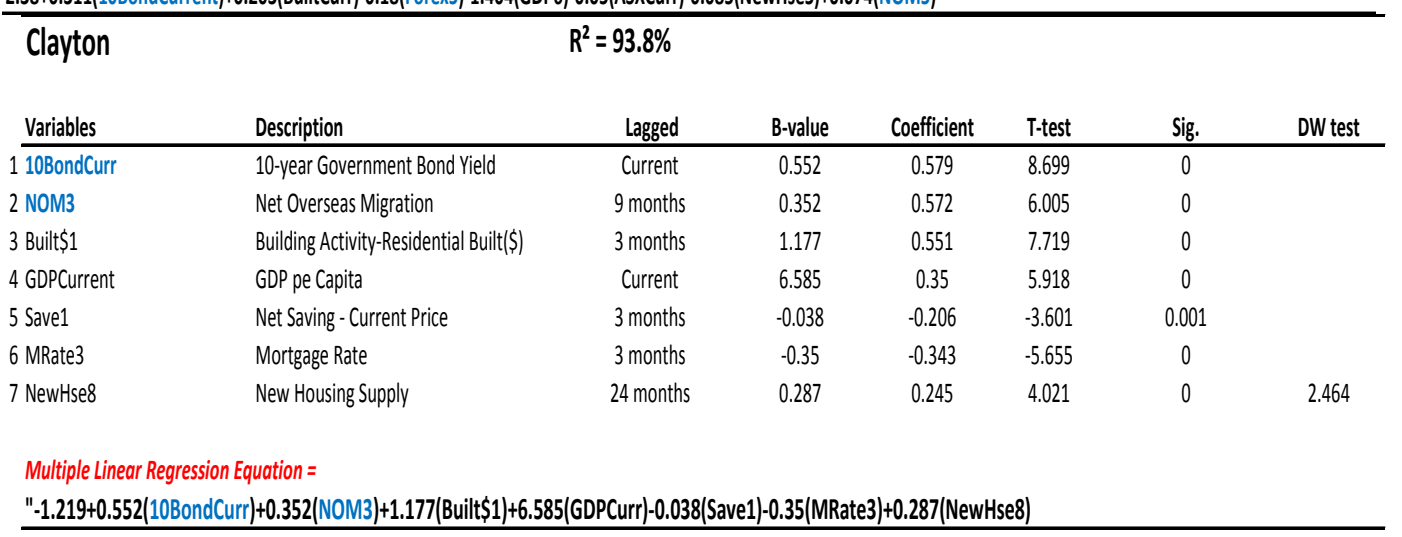

Table 1: Single Equation Regression Model for Melbourne Metropolitan and Clayton Residential Property Market 


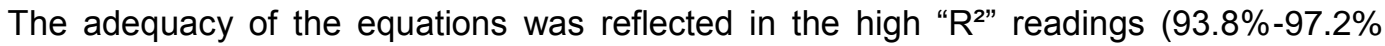
range) and the significant t-values for each economic variable. The Durbin Watson Test (DW test) showed the residual error deviations are uncorrelated for all models. Whereas the coefficient ( $r$ ) measured the correlation between the observed value and the predicted value, the B-value was computed to assess the strength of the relationship between each predictor variable to the criterion variable. Figure 4 and 5 presents the diagrams comparing the actual house prices index to the forecasting model's for the two residential property markets under the assessment:

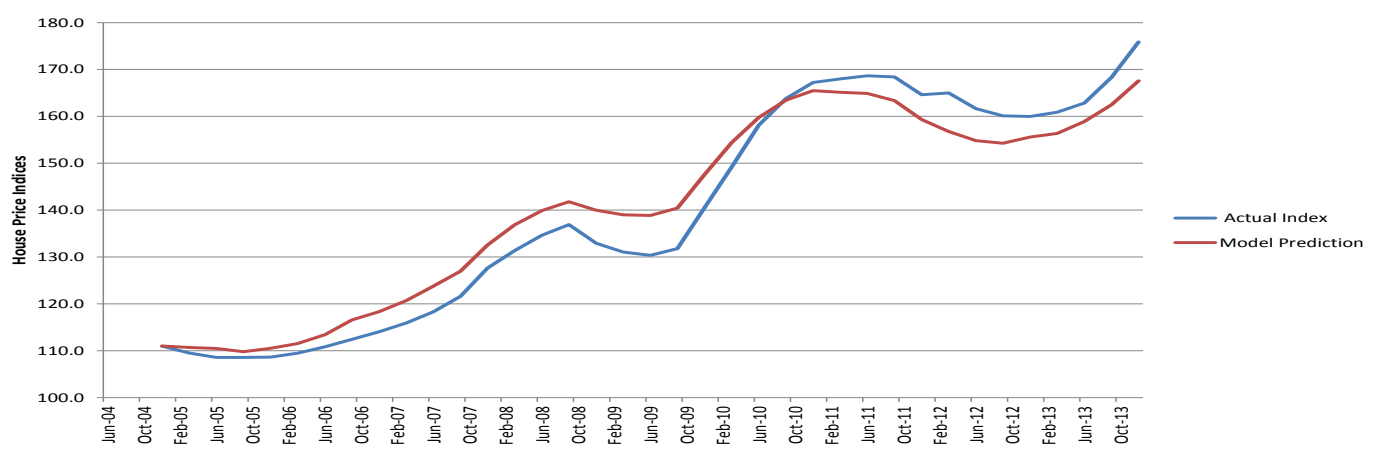

Figure 4: Melbourne Metropolitan - Forecasting Model Compared to Actual House Price Index

As per Figure 4, the forecasted house price index demonstrated similar trend as the actual index for the Melbourne Metropolitan market with a relatively lower elevation from December 2010 to December 2014. To further validate the regression equation, the forecast house prices were compared with the actual house prices of Melbourne Metropolitan for an extended 12 months subsequent to December 2014 in Table 2 as below:

\begin{tabular}{cccc}
\hline Period & Actual & Model Prediction & Difference \\
\hline Dec-13 & 175.9 & 167.58 & $-4.72 \%$ \\
Mar-14 & 182.3 & 171.42 & $-5.99 \%$ \\
Jun-14 & 189.9 & 175.10 & $-7.81 \%$ \\
Sep-14 & 193.2 & 177.47 & $-8.16 \%$ \\
Dec-14 & 196.1 & 179.42 & $-8.48 \%$ \\
\hline
\end{tabular}

Table 2: Extended 12 months Forecast - Melbourne Metropolitan

The Model prediction derived a $7.07 \%$ growth in the 12 month period (from 167.58 to 179.42) and the actual index for house prices in Melbourne Metropolitan in 2014 showed $11.47 \%$ increase (175.90 to 196.10). As a result, there was a $-8.48 \%$ difference in December 2014 comparing the actual index and forecasted index. This regression equation is considered moderately accurate with a single digit percentage difference $(-8.48 \%)$ in forecasting the residential property market performance of Melbourne. Figure 5 below presents the diagrams comparing the actual house prices index to the forecasting model's for Clayton: 


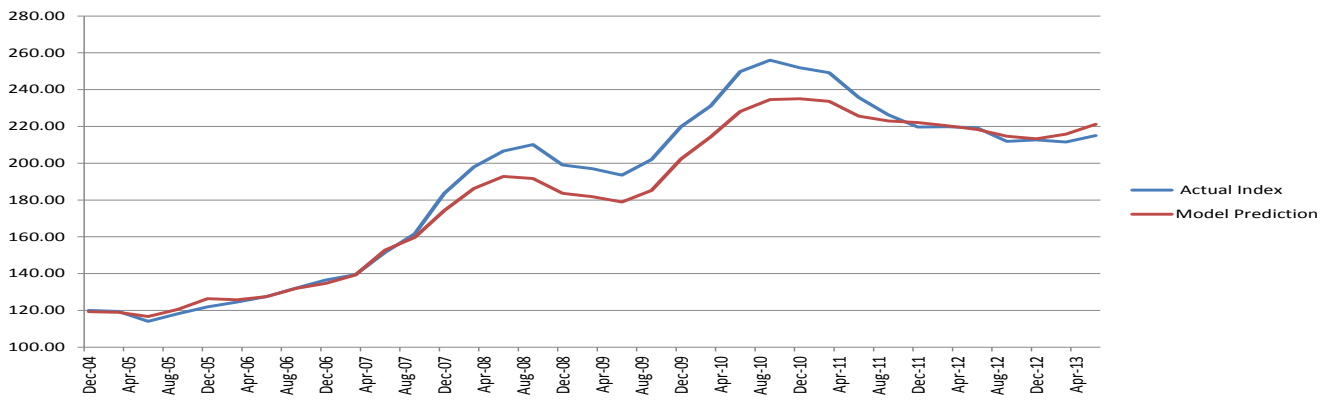

Figure 5: Clayton - Forecasting Model Compared to Actual House Price Index

Figure 5 shows accurate forecast in two intervals from December 2004 to December 2007 (before GFC 2008) and September 2011 to September 2013. To further validate the regression equation, the forecast house prices were compared with the actual house prices of Clayton for an extended 12 months subsequent to December 2014 in Table 3 as below:

\begin{tabular}{|c|c|c|c|}
\hline Period & Actual & Model Prediction & Difference \\
\hline Jun-13 & 214.99 & 221.10 & $2.84 \%$ \\
\hline Sep-13 & 230.16 & 234.90 & $2.06 \%$ \\
\hline Dec-13 & 241.61 & 246.47 & $2.01 \%$ \\
\hline Mar-14 & 257.29 & 250.41 & $-2.67 \%$ \\
\hline Jun-14 & 266.99 & 259.77 & $-2.70 \%$ \\
\hline
\end{tabular}

Table 3: Extended 12 months Forecast - Melbourne Clayton

The Model prediction derived a $17.49 \%$ growth in the 12 month period (from 221.10 to 259.77) and the actual index for house prices in Clayton showed larger $24.19 \%$ increase (175.90 to 196.10). There was a relatively smaller difference of $-2.70 \%$ in June 2014 comparing the actual index and forecasted index. This regression equation is considered accurate producing a lessor than $5 \%$ percentage difference $(-2.70 \%)$ forecasting model for the residential property market in Clayton.

Among the leading economic indicators, factors associated with foreign investment such as 10-year Government Bond Yields (10Bond), Foreign Currency Exchange (Forex) and Net Overseas Migration (NOM) emerged as leading components of the regression equations. According to Bowe (2012), Australia's second largest export was actually the Australian Commonwealth Government Bonds (ACGBs). As at June 2015, the Australian Office of Financial Management (AOFM, 2015) reported that approximately $65.2 \%$ of the Australian Government Securities (Treasury Bonds, Treasury Indexed Bonds, and Treasury Notes) were in the hands of foreign investors. Rich Asia Pacific investors are investing substantially into the Australia residential property market, both as foreigners and tourists, due to the renowned favourable living conditions and standards of education in Australia (Wong, Higgins and Wakefield, 2016). Net Overseas Migration (NOM) was one of the major traditional drivers of Melbourne residential property markets in this study and is consistent with various empirical studies (for example Benson, 2009, Borjas, 1994). The significant negatively correlated relationship between the Foreign Exchange Rate (Forex) is consistent with the overseas investment stratagem. Australian assets became more economically affordable when Australian currency was devalued against other foreign currencies. The 
foreign exchange factor is particularly relevant in terms of holding long terms assets such as properties from the investors' perspective.

\section{CONCLUSION}

The aim of this study is to explore evidences of a relationship between overseas investments and the Australian residential housing markets performance, particularly in areas that has experienced significant growth subsequent to GFC 2008. This research falls into this classification of a "predictive" design method whereby house prices in the selected suburbs will be forecasted to predict the future trend and validated using latest actual house prices data. Two statistical tests were applied to analyse the strength of the relationships between the dependent variables (House Prices) and independent variables (Australian Leading Economic Indicators) to confirm the validity of the model.

Both of the forecasting models have demonstrated a consistent pattern displaying the significant determinants for the respective residential property market performances. The factors associated with offshore investments have emerged significant and form part of major determinants among the traditional economic indicators. For example, 10-year Government Bond Yields, Foreign Currency Exchange and Net Overseas Migration were significantly correlated and emerged as leading components of the regression equations. They surpassed the importance of many other traditional residential market determinants such as rent growth, GDP per capital growth and net saving rates. As foreign investors keenly pursue an alternative asset class as part of their diversified portfolio, real estate had emerged as a crucial asset class alongside with ACGBs with similar investment trend observed. This study noted the emergence of private wealth in global real estate investment. As Asia Pacific nations and their citizens are getting more affluent and enjoying life styles previously deemed not possible, history repeats itself in that these affluent Asia Pacific citizens are now embracing the lifestyles previously exclusive to the rich western nations. One of the lifestyle trends is residential tourism.

Current evaluation measures on Australian residential property market performance are perceived inadequate due to its performance evaluation being heavily focused on domestic conditions and drivers. As the world is becoming more transparent fuelled with globalisation and advancement in information technologies, these favourable drivers are fast acted upon by global real estate investors engaging in cross border real estate transactions in Australia. This research introduces a "Higgins \& Peng" model to inclusively capture the global investments trend with "push factors" form part of the important evaluation platform. This research addresses the significance of FREI in Melbourne residential property market and provided a renewed platform for future valuation exercise and research conduct. Future studies on the related capitalist and non-capitalist drivers can shed crucial and meaningful insights on the Australian real estate market performance. 


\section{References}

ABS 2015. 6416.0-Residential Property Price Indexes: Eight Capital Cities, Sep 2015. Australian Bureau of Statistics, Canberra, viewed 10 October 2015, <http://www.abs.gov.au/ausstats/abs@.nst/mf/6416.0>

AFP. 2014. Chinese To Splurge \$39bn on Australian homes: study. Agence France-Presse, 5 March, viewed 12 March 2014, <https://sg.news.yahoo.com/chinese-splurge-39-bnaustralian-homes-study-075405722--finance.html>

ALLEN, L. 2015. Chinese Precise On Where To Buy. the Australian Financial Review, 22 July, viewed 23 July 2015 , <http://www.theaustralian.com.au/subscribe/news/1/index.html?sourceCode=TAWEB _WRE170_a\&mode=premium\&dest=http://www.theaustralian.com.au/business/busine ss-spectator/australia-is-still-hot-property-for-foreign-investors>

AOFM 2015. Non-resident Holdings Of Australian Government Securities (Treasury Bonds, Treasury Indexed Bonds, Treasury Notes). In: MANAGEMENT, A. O. O. F. (ed.). Canberra: Australian Bureau of Statistics

BENSON, M. \& O'REILLY, K. 2009. Migration and the search for a better way of life: a critical exploration of lifestyle migration. The Sociological Review, 57, 608-625

BIRRELL, B. 2013. Melbourne's High Rise Apartment Boom. CPUR Research Report September 2013.

BORJAS, G. J. 1994. The Economics of Immigration. Journal of Economic Literature, 32, 1667-1717.

BOWE, A. 2012. 'Australia's Second-Largest Export - It Isn't Coal', PIMCO, September 2012, viewed 20 July 2015, <http://europe.pimco.com/en/insights/pages/australias-secondlargest-export-it-isnt-coal.aspx>

BOYNE, S., CARSWELL, F. \& HALL, D. 2002. Reconceptualising VFR tourism. Tourism and Migration. Canberra: Springer.

COMMONWEALTHBANK, A. 2014. Demand and House Prices. Global Market Research Eonomics: Issues. Sydney: Australian Commonwealth Bank.

CORELOGIC 2016. Housing Affordability Report December 2016, CoreLogic Asia Pacific, Sydney, viewed 10 March 2017, <https://www.corelogic.com.au/reports/CL_HousingAffordability-Dec_2016.pdf>CULEM, C. G. 1988. The locational determinants of direct investments among industrialized countries. European economic review, 32, 885-904.

CUSHMAN, D. O. 1987. US bilateral trade balances and the dollar. Economics Letters, 24, 363-367.

D'ARCY, É. 2009. The evolution of institutional arrangements to support the internationalisation of real estate involvements: Some evidence from Europe. Journal of European Real Estate Research, 2, 280-293.

DWYER, L. 2010. Migration-Related Determinants Of Australian Inbound And Outbound Tourism Flows. Sustainable Tourism Cooperative Research Centre.

DWYER, L., FORSYTH, P., BURNLEY, I. \& MURPHY, P. 1993. Economic impacts of migration induced inbound tourism. Discussion Paper Series-School of Business \& Technology, University of Western Sydney.

ECONOMICS, H. S. C. O. 2014, Inquiry into foreign investment in residential real estate. Committee activities (inquiries and reports), House Standing Committee on Economics, viewed 25 July 2014, <http://www.aph.gov.au/Parliamentary_Business/Committees/House_of_Representati ves_Committees?url=economics/foreigninvestment/index.htm> 
ECONOMIST 2012, The New Landscape of Foreign Investment into China, The Economist, viewed 12 August 2014, <http://pages.eiu.com/rs/eiu2/images/EIU_ChinaFDIJan2012_Final.pdf>

ERNST\&YOUNG 2013, 'Hitting The Sweet Spot The Growth of the Middle Class In Emerging Market', Ernst \& Young, viewed 8 June 2015, <http://www.ey.com/Publication/vwLUAssets/Hitting_the_sweet_spot/\$FILE/Hitting_th e_sweet_spot.pdf>

ERNST\&YOUNGCHINA 2015, 'Riding The Silk Road: China Sees Outbound Investment Boom', Ernst \& Young China, viewed 10 July 2015, $<$ http://www.ey.com/Publication/vwLUAssets/ey-china-outbound-investment-reporten/\$FILE/ey-china-outbound-investment-report-en.pdf>

FIRB 2013, Annual Report 2012-13. In: BOARD, F. I. R. (ed.), industry report, Foreign Investment Review Board, viewed 5 May 2014, retrieved from $<$ https://firb.gov.au/files/2015/11/FIRB-Annual-Report-2012-13.pdf>

FREY, B. S., SCHNEIDER, F. \& POMMEREHNE, W. W. 1985. Economists' opinions on environmental policy instruments: analysis of a survey. Journal of Environmental Economics and Management, 12, 62-71.

FROOT, K. A., PEROLD, A. F. \& STEIN, J. C. 1991. Shareholder trading practices and corporate investment horizons. National Bureau of Economic Research.

GARNAUT, J. 2015, 'Five Million Visas Into Australia This Year Likely To Set New Records, The Age, 22 April, viewed 5 May 2015, <http://www.smh.com.au/federalpolitics/political-news/five-million-visas-into-australia-this-year-likely-to-set-newrecords-20150421-1mq6km.html>

GLYNN, J. 2017, ' National house price growth at 10.9pc in 2016: CoreLogic', The Australian, 3 January, viewed 20 April 2017, < http://www.theaustralian.com.au/business/property/national-house-price-growth-at109pc-in-2016-corelogic/news-story/0181a6fa323f09b3aff8cf27d492aa2c>

GOLDBERG, L. G. \& JOHNSON, D. 1990. The determinants of US banking activity abroad. Journal of International Money and Finance, 9, 123-137.

GUEST, R., ROHDE, N. 2015. Was the housing boom in Sydney and Melbourne driven by foreign buyers?, the Conversation, 21 December, viewed 2 May 2016, < http://theconversation.com/was-the-housing-boom-in-sydney-and-melbourne-drivenby-foreign-buyers-51389>

HAWTHORNE, L. 2010. "Two-Step Migration"? Labor Market Outcomes for International Student Migrants to Australia. Asian and Pacific Migration Journal, 19, 5.

HIGGINS, D. 2010. The Impact of the Political Cycle on House Prices: The Australian Experience. Asian Real Estate Society Conference.

HIGGINS, D. \& REDDY, W. 2010. The impact of political risk on Australian house prices. Australian and New Zealand Property Journal, 2, 413-422.

HOESLI, M., LEKANDER, J. \& WITKIEWICZ, W. 2004. International evidence on real estate as a portfolio diversifier. Journal of Real Estate Research, 26, 161-206.

JANDA, M. 2014, 'Chinese buyers to invest $\$ 44 \mathrm{~b}$ in Australian real estate', ABC News, 5 March, viewed 10 March 2014, <http://www.abc.net.au/news/2014-03-05/chinesebuyers-to-invest-44-billion-dollars-in-australian-real-/5300494>

KHARAS, H. 2010. The Emerging Middle Class in Developing Countries. OECD Working Paper, 285.

KING, B. 1994. What is ethnic tourism? An Australian perspective. Tourism Management, 15, 173-176.

KING, N., CASSELL, C. \& SYMON, G. 1994. Qualitative methods in organizational research: A practical guide. The Qualitative Research Interview. 
KPMG 2014. Demystifying China Investment in Australia. Sydney: KPMG.

LUCAS, C. 2015, 'Melbourne Named World's Most Liveable City, For Fifth Year Running', The Age, 19 August, viewed 19 August 2015, $<$ http://www.theage.com.au/victoria/melbourne-named-worlds-most-liveable-city-forfifth-year-running-20150818-gj1 he8.html>

MOSHIRIAN, F. \& PHAM, T. 2000. Determinants of US investment in real estate abroad. Journal of Multinational Financial Management, 10, 63-72.

NAB 2015, NAB Residential Property Survey: Q1 2015, National Australia bank, viewed 1 May 2015, <http://business.nab.com.au/wp-content/uploads/2015/04/QuarterlyAustralian-Residential-Property-Survey-Q1-2015-PDF202KB.pdf>

NIGH, D. W., CHO, K. R. \& KRISHNAN, S. 1986. The role of location-related factors in US banking involvement abroad: an empirical examination. Journal of International Business Studies, 17, 59-72.

O'REILLY, K. 2007. Emerging tourism futures: Residential tourism and its implications.

PASCOE, M. 2015, 'Foreign Students Set To Power Housing', The Sydney Morning Herald Business Day, 4 August, viewed 10 August 2015, < http://www.smh.com.au/business/comment-and-analysis/foreign-students-set-topower-housing-20150803-giq47c.html>

RODRÍGUEZ, C. \& BUSTILLO, R. 2010. Modelling foreign real estate investment: The Spanish case. The Journal of Real Estate Finance and Economics, 41, 354-367.

ROSE, S. 2015, 'Illegal Foreign Property Buying Inevitable, says FIRB', The Age, 25 March, viewed 30 March 2015, <http://www.smh.com.au/business/the-economy/illegalforeign-property-buying-inevitable-says-firb-20150324-1m6bel.html>

SAVILLS 2014, Around The World In Dollars and Cents - How Private Money Moves Around The Real Estate World, Savills World Research 2014, viewed 20 July 2014, <http://www.savills.co.uk/research_articles/188297/171998-0>

SCHLESINGER, L. 2015, 'Chinese property buyer myths busted', Financial Review, 1 March, viewed 8 March 2015, <http://www.afr.com/real-estate/residential/chineseproperty-buyer-myths-busted-20150227-13r0n4>

SOOS, P. 2012. Don't blame foreign investment for rising house prices, the Conversation, 1 August, viewed 2 May 2016, < http://theconversation.com/dont-blame-foreigninvestment-for-rising-house-prices-8340>

TASHAKKORI, ABBAS., \& TEDDLIE, CHARLES 2010. Sage handbook of mixed methods in social \& behavioral research (2nd ed.). SAGE Publications, Los Angeles

TEDDLIE, C. \& TASHAKKORI, A. 2009. Foundations of mixed methods research: Integrating quantitative and qualitative approaches in the social and behavioral sciences, Sage Publications Inc.

TEDDLIE, C. \& YU, F. 2007. Mixed methods sampling a typology with examples. Journal of mixed methods research, 1, 77-100.

TIMESHIGHEREDUCATION 2015, 'World University Rankings', Times Higher Education, viewed 23 October 2015, < https://www.timeshighereducation.com/world-universityrankings/2015/world-

ranking\#!/page/0/length/25/sort_by/rank_label/sort_order/asc/cols/rank_only>

TOPINTZI, E., CHIN, H. \& HOBBS, P. 2008. Moving towards a global real estate index. Journal of Property Investment \& Finance, 26, 286-303.

UNCTAD 2009, World Investment Report 2009 - Transnational Corporations, Agricultural Production and Development, United Nation Conference on Trade and Development, viewed 5 April 2014, <http://unctad.org/en/docs/wir2009_en.pdf>

UNCTAD 2011, NON-EQUITY MODES OF INTERNATIONAL PRODUCTION AND DEVELOPMENT. World Investment Report 2011. United Nation Conference on Trade 
and Development, viewed 28 April 2014, < http://unctad.org/en/pages/PublicationWebflyer.aspx?publicationid=84>

UNCTAD 2013. World Investment Report 2013 - Global Value Chains: Investment And Trade For Development. United Nations Conference on Trade and Development, viewed 28 April 2014, $<$ http://unctad.org/en/pages/PublicationWebflyer.aspx?publicationid=588>

WILLIAMS, A. \& HALL, C. M. 2002. Tourism, migration, circulation and mobility. In: HALL, C. M. \& WILLIAMS, A. (eds.) Tourism and Migration. Springer Netherlands.

WILLIG, C. 2013. Introducing qualitative research in psychology, McGraw-Hill Education (UK).

WILSON, D. 2008. The Expanding Middle: The Exploding World Middle Class and Falling Global Inequality. Goldman Sachs Global Economy Paper, 170.

WONG, P. 2017. 'Foreign Real Estate Investment and the Australian Residential Property Market: A Study on Chinese Investors', World Academy of Science, Engineering and Technology, International Science Index, Economics and Management Engineering, 4(6), 3444.

WONG, P., HIGGINS, D. \& WAKEFIELD, R. 2017. Foreign Real Estate Investment, Residential Tourism and The Australian Residential Property Market, International Journal of Housing Markets and Analysis(to be published)

YIN, R. K. 2013. Case study research: Design and methods, Sage publications. 